\title{
Persepsi Guru Terhadap Penerapan Sistem Full Day School: Studi Kasus di SMAN 1 Citeureup
}

\author{
Novi Anggraeni' ${ }^{1}$, Baeti Rohman ${ }^{2}$, Aas Siti Sholichah ${ }^{3}$ \\ ${ }^{1}$ Fakultas Tarbiyah, Institut PTIQ Jakarta, Indonesia \\ ${ }^{2}$ Fakultas Tarbiyah, Institut PTIQ Jakarta, Indonesia \\ ${ }^{3}$ Fakultas Tarbiyah, Institut PTIQ Jakarta, Indonesia \\ ${ }^{1}$ novianggraeni0@gmail.com \\ ${ }^{2}$ baetirohman@ptiq.ac.id \\ ${ }^{3}$ sholichah@gmail.com
}

\begin{abstract}
Abstrak:
Tulisan ini membahas tentang persepsi guru terhadap penerapan sistem full day school yang di SMAN 1 Citeureup. Penelitian ini dilatar belakangi oleh adanya sebuah inovasi dalam pendidikan yang ditetapkan oleh pemerintah tentang hari sekolah yaitu full day school. Jenis penelitian ini adalah penelitian kualitatif deskriptif dengan pendeketan studi lapangan (field research). Adapun teknik pengumpulan data penelitian ini menggunakan observasi, wawancara dan dokumentasi. Hasil penelitian ini menunjukan bahwa (1) Sebagian guru memberikan respon positif terhadap kebijakan full day school, bilamana sekolah tersebut mampu menunjang segala aspek yang dibutuhkan baik oleh guru maupun siswa, mulai dari konsep pengelolaan pembelajaran full day school yang terencana dengan baik, terstruktur dan terarah sehingga lebih efektif dalam menjalankan proses pembelajarannya serta pengembangan sarana dan prasarana yang memadai (2) persepsi guru tentang kelebihan full day school sistem ini mampu menjadi solusi bagi para orang tua yang peduli terhadap krisis moral yang sedang dialami para siswa saat ini. Selanjutnya sebagai sarana perbaikan kualitas akhlak siswa menjadi lebih baik, dan untuk memaksimalkan waktu siswa agar lebih bermanfaat dengan mengembangkan bakat, minat dan kreativitas siswa (3) persepsi guru terhadap kelemahan full day school terletak pada teknis pelaksanaanya di sekolah, minimnya sosialisasi siswa dengan lingkungan sekitar tempat tinggalnya serta sarana dan prasarana yang kurang memadai (4) pengelolaan pembelajaran full day school di SMAN 1 Citeureup sesuai dengan yang tercantum dalam PP No. 19 Tahun 2005 tentang Standar Nasional Pendidikan yang meliputi perencanaan program, pelaksanaan dan evaluasi.
\end{abstract}

Kata Kunci: Persepsi Guru, Full Day School, Pengelolaan Pembelajaran

\begin{abstract}
:
This paper discusses the teacher's perception of the application of the full day school system at SMAN 1 Citeureup. This research is motivated by the existence of an innovation in education set by the government about the school day that is full day school. This type of research is a descriptive qualitative research with field research approach. The research data collection techniques using observation, interviews and documentation. The results of this study indicate
\end{abstract}


that (1) Some teachers respond positively to the full day school policy, if the school is able to support all aspects needed by both teachers and students, starting from the concept of managing a full day school learning that is well planned, structured and directed so that it is more effective in carrying out the learning process and the development of adequate facilities and infrastructure (2) teachers' perceptions about the advantages of full day school systems can be a solution for parents who care about the moral crisis that is being experienced by students at this time. Furthermore, as a means of improving the quality of student morals for the better, and to maximize student time to be more useful by developing students 'talents, interests and creativity (3) teachers' perceptions of the weaknesses of full day school lies in the technical implementation in schools, the lack of student socialization with the surrounding environment inadequate places of residence and facilities and infrastructure (4) management of full day school learning in SMAN 1 Citeureup in accordance with PP No. 19 of 2005 concerning National Education Standards which include program planning, implementation and evaluation.

Keywords: Teacher's Perception, Full Day School, Learning Management

\section{Pendahuluan}

Salah satu upaya pemerintah dalam melakukan inovasi-inovasi yang berkualitas bagi pendidikan di Indonesia yaitu diselenggarakannya sistem Full Day School. Muhadjir Effendy, telah menetapkan Peraturan Menteri (Permen) Nomor 23 Tahun 2017 tentang Hari Sekolah, yang mengatur sekolah 8 jam sehari selama 5 hari dalam sepekan, dan resmi diterapkan pada tahun ajaran 2017-2018. Namun bagi sekolah yang belum memiliki sumber daya dan sarana prasana yang memadai, maka kebijakan ini akan dilakukan secara bertahap. ${ }^{1}$

Full day school adalah sekolah sepanjang hari atau proses belajar mengajar di sekolah yang dilakukan mulai pukul 07.00 sampai 16.00 dengan durasi istirahat setiap dua jam sekali dimana jadwal pelajaran disesuaikan dengan bobot mata pelajaran dan ditambah dengan pendalaman materi. ${ }^{2}$

Menurut data yang disajikan oleh ANTARANEWS, sedikitnya ada 5.000-10.000 sekolah negri dan swasta telah menerapkan sistem full day school. ${ }^{3}$ Baharudin menyatakan bahwa konsep pengembangan dan inovasi pembelajaran sistem full day school didesain untuk mengembangkan kreativitas anak mencakup aspek kognitif, afektif, dan psikomotorik. ${ }^{4}$. Sebagai sebuah inovasi progresif dalam dunia pendidikan, full day school memiliki daya tarik yang tidak lepas dari berbagai keunggulan dan keistimewaannya. Diantaranya adalah siswa

\footnotetext{
1 http://disdik.jabarprov.go.id/news/237/mendikbud-tetapkan-peraturan-menteri-nomor-23-tahun-2017-tentanghari-sekolah\#. Diakses pada tanggal 17 Mei 2019.

${ }^{2}$ Suyyinah, Full Day Education; Konsep dan Implementasi, (Malang: CV. Literasi Nusantara Abadi, 2019), h. 11.

3 Https://m.antaranews.com/amp/berita/618878/10000-sekolah-daftar-terapkan-full-day-school. Diakses pada tanggal 17 Mei 2019.

${ }^{4}$ Baharudin, Pendidikan dan Psikologi Perkembangan, (Yogyakarta: Ar-Ruzz Media, 2010), h. 223.
} 
dididik secara langsung bagaimana memanfaatkan waktu secara efisien dan produktif, menggali, mengembangkan dan memaksimalkan minat, bakat dan potensinya serta memudahkan kalangan pendidik dan orangtua dalam mengontrol perkembangan psikologi, moralitas, spiritualitas dan karakter anak. ${ }^{5}$

Kendati demikian, dalam penerapannya, full day school bukan berarti tidak mempunyai problem. Ada beberapa kelemahan pada penerapannya. Diantara fenomena yang terjadi pada sekolah dengan sistem full day school yaitu jam sekolah yang padat berpengaruh pada minimnya interaksi sosial anak diluar sekolah. Selain itu, kurikulum full day school yang kurang memperhatikan kondisi fisik dan psikis anak karena kegiatan dilaksanakan sampai sore hari. Sekolah full day school selama ini dikenal dengan biaya pendidikan yang cukup besar sehingga menyebabkan terjadinya dikotomisasi pendidikan. Masyarakat berekonomi lemah kemungkinan besar tidak bisa mengakses sekolah ini.

Dengan berbagai keunggulan dan kelemahan full day school diatas, tentunya menuai banyak persepsi dari berbagai kalangan masyarakat, termasuk dari salah satu komponen pendidikan itu sendiri. Komponen tersebut adalah pendidik yaitu guru. Guru merupakan faktor penentu yang sangat dominan dalam pendidikan pada umumnya, karena guru memegang peranan dalam proses pembelajaran di sekolah, dimana proses pembelajaran merupakan inti dari proses pendidikan secara keseluruhan. ${ }^{6}$

\section{A. Metode Penelitian}

Dalam penelitian ini, penulis menggunakan jenis penelitian deskriptif kualitatif dengan pendekatan penelitian studi lapangan (field research), yaitu penelitian yang menekankan analisisnya pada proses penyimpulan induktif serta pada analisis terhadap dinamika hubungan antara fenomena yang diamati dengan menggunakan logika ilmiah. ${ }^{7}$ Field research (studi lapangan) adalah melakukan penelitian di lapangan untuk memperoleh data atau informasi secara langsung dengan mendatangi responden. ${ }^{8}$ Adapun teknik yang digunakan dalam pengumpulan data pertama, Observasi, yaitu cara menghimpun (data) bahan-bahan keterangan yang dilakukan dengan melakukan pengamatan dan pencatatan secara sistematis terhadap fenomena-fenomena yang sedang dijadikan sarana pengamatan. ${ }^{9} \mathrm{Kedua}$, wawanca, yaitu

\footnotetext{
5 Jamal Ma'mur Asmani, Full Day School; Kensep Manajemen \& Quality Control, h. 31-49.

${ }^{6}$ Rusman, Model-Model Pembelajaran Mengembangkan Profesionalisme Guru, Cetakan Ke-6, (Jakarta: Rajawali Pers, 2016), h. 58.

${ }^{7}$ Mahmud,Metode Penelitian Pendidikan, (Bandung: Pustaka Setia, 2001(, h.81.

${ }^{8}$ Rosady Ruslan, Metode Penelitian Public Relations dan Komunikasi, (Jakarta: Rajagrafindo, 2008), h. 32.

${ }^{9}$ Irwan Soeharto, Metode Penelitian Sosial, (Bandung, PT Remaja Rosdakarya, 1995) Hal. 65.
} 
pengumpulan data dengan cara tanya jawab antara pewawancara dengan yang diwawancarai, dan jawaban responden dicatat dan direkam dengan alat perekam. Ketiga, Dokumentasi, yaitu sebuah proses yang dilakukan untuk menyediakan dokumen-dokumen dengan menggunakan bukti yang akurat dari pencatatan sumber-sumber informasi khusus dari tulisan, wasiat, buku, undang-undang dan lain sebagaimya.

\section{Konsep Persepsi Guru dan Full Day School}

Secara etimologis, persepsi atau dalam Bahasa Inggris perception berasal dari bahasa latin perceptio; dari percipere; yang artinya menerima atau mengambil. ${ }^{10}$ Dalam Kamus Besar Bahasa Indonesia (KBBI), persepsi adalah tanggapan. ${ }^{11}$ Persepsi secara istilah dapat didefinisikan sebagai proses mengorganisasi dan menafsirkan pola stimulus dalam lingkungan. ${ }^{12}$ Persepsi dapat (perception) dapat diartikan juga sekumpulan tindakan mental yang mengatur impuls-impuls sensorik menjadi suatu pola yang bermakna. ${ }^{13}$

Persepsi merupakan proses yang hampir bersifat otomatik dan ia bekerja dengan cara yang hampir serupa pada masing-masing individu, tetapi dapat menghasilkan persepsi yang berbeda-beda. ${ }^{14}$ Persepsi merupakan suatu proses yang didahului oleh proses penginderaan yaitu merupakan proses diterimanya stimulus oleh individu melalui alat indera.

Berdasarkan pengertian-pengertian yang telah dipaparkan diatas, maka dapat disimpulkan bahwa persepsi adalah asumsi terhadap sesuatu, baik diri sendiri, mauoun orang lain, dan juga kejadian-kejadian dalam hidup berdasarkan sudut pandang sendiri yang diperoleh dengan menggunakan indera penglihatan, penciuman, perasaan, perabaan dan pendengaran.

Dalam Kamus Besar Bahasa Indonesia (KBBI), guru diartikan sebagai orang yang pekerjaannya (mata pencahariannya, profesinya) mengajar. ${ }^{15}$ Kata guru dalam bahasa Arab disebut sebagai mu'allim dan dalam bahasa Inggris disebut teacher itu memiliki arti sebagai $a$ person whose occupation is teaching others ${ }^{16}$

Berdasarkan Undang-Undang No. 20 Tahun 2003 tentang Sistem Pendidikan Nasional pasal 39 ayat 1 dijelaskan bahwa pendidik adalah tenaga profesional yang bertugas

\footnotetext{
${ }^{10}$ Alex Sobur, Psikologi Umum Dalam Lintasan Sejarah, (Bandung: Pustaka Setia, 2013), h. 445.

${ }^{11}$ Pengertian persepsi terdapat di Https://kbbi.web.id/persepsi.html, diakses pada tanggal 18 Desember 2019.

${ }^{12}$ Nurdjannah Taufiq dan Rukmini Barhana, Pengantar Psikologi, (Jakarta: Erlangga, 2003), h. 208.

${ }^{13}$ Carol Wade \& Carol Travis, Psikologi Edisi Ke-9, (Jakarta: Erlangga, 2009), h. 193.

${ }^{14}$ Winardi, Motivasi Dan Pengorganisasian Dalam Manajemen, (Jakarta: Rajawali Pers, 2008), h. 46.

${ }^{15}$ Departemen Pendidikan dan Kebudayaan, Kamus Besar Bahasa Indonesia, (Jakarta: Balai Pustaka, 2009), h. 288.

${ }^{16}$ Muhibbin Syah, Psikologi Pendidikan dengan Pendekatan Baru, (Bandung: PT. Remaja Rosdakarya, 2002), h. 222.
} 
merencanakan dan melaksanakan proses pembelajaran, menilai hasil pembelajaran, melakukan pembimbingan dan pelatihan, serta melakukan penelitian dan pengabdian kepada masyarakat, terutama bagi pendidik pada perguruan tinggi. ${ }^{17}$

Sehingga dalam konteks ini dapat disimpulkan bahwa guru adalah tenaga professional yang pekerjaan utamanya mengajar dan mendidik sebagai bentuk pengabdian kepada komunitas belajar (learning community) atau dalam lingkup lebih luas ke masyarakat, bangsa dan negara. Dengan kesimpulan tersebut, maka setiap aktivitas yang dilakukan seseorang dalam konteks pendidikan akan terejawantahkan dalam bentuk sebagai fasilitator, inisiator, mediator ataupun sebagai evaluator.

Guru adalah pendidik professional dengan tugas utama mendidik, mengajar, membimbing, mengarahkan, melatih, menilai dan mengevaluasi. ${ }^{18}$ Dengan adanya tugas tersebut, guru merupakan salah satu komponen pendidikan yang sangat berperan dalam usaha pembentukan sumber daya manusia yang potensial dan berkualitas. Oleh karena itu, guru harus berperan secara efektif dan menempatkan kedudukannya sebagai tenaga professional sesuai dengan tuntutan masyarakat yang semakin berkembang.

Sebagai tenaga professional, guru harus siap untuk mengikuti perkembangan zaman. Guru harus siap jika sewaktu-waktu pemerintah mengubah kebijakannya. Karena memang kebijakan pemerintah semata-mata untuk perbaikan kualitas pendidikan yang ada di Indonesia sehingga bisa menghasilkan output yang berkualitas, handal dan ahli dalam bidangnya.

Ketika pemerintah membuat kebijakan full day school, sekolah-sekolah diharapkan bisa mengubah program mereka menjadi full day school terkecuali pada sekolah-sekolah yang belum memadai. Hal ini menunjukan bahwa guru sebagai pengajar di sekolah juga harus siap untuk berubah mengikuti perkembangan dari sekolah tersebut. Kendati demikian, dengan diterapkannya sistem full day school menuai berbagai persepsi dikalangan guru-guru baik itu yang setuju maupun yang tidak setuju.

Full day school merupakan salah satu upaya pemerintah dalam melakukan inovasiinovasi yang berkualitas bagi pendidikan di Indonesia. Sistem ini ditetapkan pemerintah sebagaimana yang tertuang dalam Peraturan Menteri Pendidikan dan Kebudayaan Nomor 23 Tahun 2017 tentang Hari Sekolah yang mengatur sekolah 8 jam sehari selama 5 hari dalam sepekan dan resmi diterapkan pada tahun 2017-2018 seiring dengan diberlakukannya Kurikulum 2013.

\footnotetext{
${ }^{17}$ Arbangi, et.al., Manajemen Mutu Pendidikan, (Depok: Prenadamedia Group, 2018), h. 149.

${ }^{18}$ Rugaiyah dan Atiek Sismiati, Profesi Kependidikan, (Bogor: Ghalia Indonesia, 2013), h. 6.
} 
Sistem Full day school yang diberlakukan di SMAN 1 Citeureup selain mengikuti aturan pemerintah untuk menerapkan sistem full day school, juga menjadikan full day school sebagai sarana atau tempat untuk membiasakan anak-anak mengisi waktu dengan kegiatan yang lebih bermanfaat dan bisa mengcover hal-hal negatif yang memungkinkan siswa lakukan sepulang sekolah sampai sore. Belajar sepanjang hari merupakan bukti penghargaan yang tinggi terhadap waktu. Itulah kelebihan pertama yang dimiliki olehh full day school. Memanfaatkan waktu secara efektif dan produktif adalah ciri-ciri orang yang akan meraih kesuksesan.

Kelebihan lainnya yaitu dengan waktu yang luas, anak-anak bisa mengembangkan bakat mereka dengan mengikuti kegiatan eskstrakurikuler maupun organisasi lainnya. Program yang terukur, terencana dan sistematis sangat dibutuhkan dalam mengembangkan bakat siswa. Full day school tidak hanya diisi dengan pelajaran kognitif ataupun afektif saja, akan tetapi harus dilengkapi dengan pembelajaran pada aspek psikomotorik. Dari sinilah bakat siswa akan cepat terdeteksi dan berkembang dengan baik.

Hal itu sesuai seperti yang dijelaskan oleh Jamal Ma'mur Asmani dalam bukunya yang berjudul Full Day School Konsep Manajemen \& Quality Control bahwa keunggulan full day school adalah untuk (a) optimalisasi pemanfaatan waktu, (b) intensif menggali dan mengembangkan bakat, (c) menanamkan pentingnya proses, (d) fokus dalam belajar, (e) memaksimalkan potensi, (f) mengembangkan kreativitas, dan (g) anak terkontrol dengan baik. $^{19}$

Dari pandangan di atas, full day school dapat melatih anak untuk senantiasa disiplin waktu karena pada full day school semua kegiatan dimulai dari sholat dhuha, belajar, istirahat, sholat dzuhur, ashar berjamaah, dan makan siang sudah dijadwalkan dengan baik. Dan dengan pembelajaran kognitif yang efektif dari hari senin-jum'at, anak-anak akan fokus dalam belajar. Hal ini diperkuat dengan hasil penelitian yang dilakukan di SMAN 1 Citeureup

\section{Deskripsi Data Hasil Penelitian}

Penelitian ini berkaitan dengan persepsi guru terhadap penerapan sistem full day school yang ditinjau dari kelebihan dan kelemahan dalam hal pembelajaran, serta pengelolaan pembelajaran full day school di SMAN 1 Citeureup. Data hasil penelitian ini diperoleh dari wawancara dengan sembilan narasumber, sebagaimana yang tertuang dalam tabel berikut ini:

\section{Tabel 1 Daftar Narasumber Penelitian}

\footnotetext{
${ }^{19}$ Jamal Ma'mur Asmani, Full Day School Konsep Manajemen \& Quality Control, h. 31-48
} 


\begin{tabular}{|l|l|l|}
\hline No & \multicolumn{1}{|c|}{ Nama } & \multicolumn{1}{|c|}{ Jabatan } \\
\hline 1 & Dra. Vera Sentra Hutabarat & Kepala Sekolah \\
\hline 2 & Asep Kurniawan, S.Pd & Wakil Kepala Sekolah Bidang Kurikulum \\
\hline 3 & Saepul Bahri, S.Pd & $\begin{array}{l}\text { Pembina Ekstrakurikuler Rohani Islam } \\
\text { (Rohis), Wali Kelas X IPA-2 dan Guru } \\
\text { Mata Pelajaran PAI }\end{array}$ \\
\hline 4 & Tengku Ahmad Avit, S.Pd & $\begin{array}{l}\text { Wakil Kurikulum Bidang Sarana dan } \\
\text { Prasarana, Wali Kelas X IPS-4 dan Guru } \\
\text { Mata Pelajaran Penjasorkes }\end{array}$ \\
\hline 5 & Rika Yosepa, M.Pd & $\begin{array}{l}\text { Koordinator Penilaian Kinerja Guru } \\
\text { (PKG), Wali Kelas XII IPA-5, dan Guru } \\
\text { Mata Pelajaran Fisika }\end{array}$ \\
\hline 6 & Euis Tuti Indrawati, S.Pd & $\begin{array}{l}\text { Wakil Kepala Sekolah Bidang Kesiswaan, } \\
\text { Wali Kelas XII IPA-3, dan Guru Mata } \\
\text { Pelajaran Biologi }\end{array}$ \\
\hline 9 & Shanti Wijaya, S.Pd & $\begin{array}{l}\text { Wali Kelas XI IPA-3 dan Guru Mata } \\
\text { Pelajaran Kimia }\end{array}$ \\
\hline 5 & & Guru Mata Pelajaran Seni Budaya \\
\hline & & Guru Mata Pelajaran PAI \\
\hline & & Ramahan Fadhel Al-Mughni \\
\hline
\end{tabular}

Selain dari wawancara dengan sembilan narasumber tersebut, hasil penelitian ini juga didapat dari observasi dan data atau dokumen dari sekolah.

\section{Persepsi Guru Terhadap Penerapan Sistem Full Day School}

Kebijakan full day school yang diterapkan oleh pemerintah tentu menuai banyak persepsi yang berbeda-beda di kalangan guru-guru. Data yang peneliti peroleh dari setiap narasumber akan disajikan dalam bentuk tabel di bawah ini:

Tabel 2. Hasil Wawancara tentang Kebijakan Full Day School

\begin{tabular}{|c|c|c|c|}
\hline No & Nama & Jabatan & Hasil Wawancara \\
\hline 1 & $\begin{array}{c}\text { Dra. Vera } \\
\text { Sentra } \\
\text { Hutabarat }\end{array}$ & Kepala Sekolah & $\begin{array}{l}\text { Full day school itu program yang } \\
\text { bagus, dari hari senin-jumat dengan } \\
\text { jam yang cukup luas dari jam 07.00- } \\
15.30 \text { anak-anak bisa belajar lebih } \\
\text { fokus dan tidak terputus. Sedangkan } \\
\text { untuk hari sabtunya tetap masuk } \\
\text { akan tetapi diisi dengan eskul, } \\
\text { pembinaan dan tausyiah. Jadi di }\end{array}$ \\
\hline
\end{tabular}




\begin{tabular}{|c|c|c|c|}
\hline & & & $\begin{array}{l}\text { sekolah ini meskipun full day } \\
\text { school, hari sabtu pun tetap masuk } \\
\text { akan tetapi agak longgar. }{ }^{20}\end{array}$ \\
\hline 2 & $\begin{array}{c}\text { Asep } \\
\text { Kurniawan, } \\
\text { S.Pd }\end{array}$ & $\begin{array}{c}\text { Wakil Kepala } \\
\text { Sekolah Bidang } \\
\text { Kurikulum }\end{array}$ & $\begin{array}{l}\text { Kalau full day school didefinisikan } \\
\text { sebagai pembelajaran dari pagi } \\
\text { sampai sore, itu saya lebih setuju } \\
\text { anak-anak lebih banyak di rumah } \\
\text { daripada di sekolah. Katakanlah } \\
\text { anak-anak di sekolah sampai jam } \\
14.00 \text { kemudian sisanya mereka } \\
\text { belajar di rumah. Kalau dulu itu ada } \\
\text { yang namanya Taman Pendidikan } \\
\text { Al-Qur'an (TPQ). Sesudah ashar } \\
\text { mereka ngaji di rumah, } \\
\text { bersosialisasi dengan lingkungan } \\
\text { setempat. Sedangkan dengan full } \\
\text { day school begitu anak pulang } \\
\text { kerumah mereka sedah kelelahan, } \\
\text { ngobrol dengan orang tuapun bisa } \\
\text { jadi sedikit dan TPQ pun berkurang } \\
\text { sedangkan di sekolah pelajaran } \\
\text { agamapun kurang hanya } 3 \text { jam } \\
\text { pelajaran dalam sepekan. }{ }^{21}\end{array}$ \\
\hline 3 & $\begin{array}{l}\text { Saepul Bahri, } \\
\text { S.Pd }\end{array}$ & $\begin{array}{c}\text { Pembina } \\
\text { Ekstrakurikuler } \\
\text { Rohani Islam } \\
\text { (Rohis), Wali Kelas } \\
\text { X IPA-2 dan Guru } \\
\text { Mata Pelajaran PAI }\end{array}$ & $\begin{array}{l}\text { Saya cukup mengapresiasi terhadap } \\
\text { kebijakan full day school ini. } \\
\text { Namun harus dimatangkan dulu } \\
\text { konsepnya, dan juga harus } \\
\text { difikirkan seperti Taman } \\
\text { Pendidikan Al-Qur'an (TPQ) yang } \\
\text { ada di masyarakat. Dengan adanya } \\
\text { full day school maka lama kelamaan } \\
\text { TPQ ini akan mengalami gulung } \\
\text { tikar. Kalau di sekolah ini meskipun } \\
\text { full day school hari sabtunya tetap } \\
\text { masuk karena eskul, dan saya harap } \\
\text { pembelajaran hanya sampai jumat } \\
\text { saja supaya sabtu dan minggu anak- } \\
\text { anak ada waktu untuk bersosialisasi } \\
\text { dengan linkungan tempat } \\
\text { tinggalnya. Tapi over all, full day } \\
\text { school sudah bagus. }{ }^{22}\end{array}$ \\
\hline
\end{tabular}

\footnotetext{
${ }^{20}$ Wawancara dengan Ibu Vera Sentra Hutabarat selaku Kepala Sekolah SMAN 1 Citeureup pada tanggal 10 Januari 2020 di Kantor Kepala Sekolah.

${ }^{21}$ Wawancara dengan Bapak Asep Kurniawan selaku Wakil Kepala Sekolah Bidang Kurikulum pada tanggal 10 Januari 2020 di Kantor Pembina.

${ }^{22}$ Wawancara dengan Bapak Saepul Bahri selaku Pembina Eskul pada tanggal 7 Januari 2020 di .
} 


\begin{tabular}{|c|c|c|c|}
\hline 4 & $\begin{array}{c}\text { Tengku } \\
\text { Ahmad Avit, } \\
\text { S.Pd }\end{array}$ & $\begin{array}{c}\text { Wakil Kepala } \\
\text { Sekolah Bidang } \\
\text { Sarana dan } \\
\text { Prasarana, Wali } \\
\text { Kelas X IPS-4 dan } \\
\text { Guru Mata Pelajaran } \\
\text { Penjasorkes }\end{array}$ & $\begin{array}{l}\text { Full day school ini merupakan } \\
\text { program yang bagus untuk } \\
\text { diterapkan apalagi di daerah } \\
\text { perkotaan yang notabene orang } \\
\text { tuanya sibuk bekerja. Dan juga } \\
\text { anak-anak sekarang yang moralnya } \\
\text { sangat memprihatinkan, program } \\
\text { full day school ini bisa menjadi } \\
\text { wadah, tempat yang bisa digunakan } \\
\text { untuk memperbaiki moral anak- } \\
\text { anak juga untuk mengisi waktu } \\
\text { luang mereka dengan hal yang } \\
\text { berguna agar tidak terbuang dengan } \\
\text { sia-sia. }\end{array}$ \\
\hline 5 & $\begin{array}{c}\text { Rika Yosepa, } \\
\text { M.Pd }\end{array}$ & $\begin{array}{c}\text { Koordinator } \\
\text { Penilaian Kinerja } \\
\text { Guru (PKG), Wali } \\
\text { Kelas XII IPA-5, } \\
\text { dan Guru Mata } \\
\text { Pelajaran Fisika }\end{array}$ & $\begin{array}{l}\text { Sepengetahuan saya mengenai full } \\
\text { day school berarti kan anak-anak } \\
\text { kesehariannya berada di sekolah, ini } \\
\text { bisa baik atau tidak dilihat dari } \\
\text { berbagai hal tentunya. Misalkan } \\
\text { saja anak itu bukan hanya untuk } \\
\text { dididik atau diajar tapi dia juga } \\
\text { harus mengembangkan } \\
\text { karakternya. Kalau memang mau } \\
\text { menerapkan full day school berarti } \\
\text { segala hal yang menunjang } \\
\text { perkembangan fisik maupun psikis } \\
\text { anak tersebut harus terpenuhi. Jadi } \\
\text { di sekolah anak harus dibuat } \\
\text { senyaman mungkin, supaya anak } \\
\text { betah di sekolah. }{ }^{24}\end{array}$ \\
\hline 6 & $\begin{array}{l}\text { Euis Tuti } \\
\text { Indrawati, } \\
\text { S.Pd }\end{array}$ & $\begin{array}{c}\text { Wakil Kepala } \\
\text { Sekolah Bidang } \\
\text { Kesiswaan, Wali } \\
\text { Kelas XII IPA-3, } \\
\text { dan Guru Mata } \\
\text { Pelajaran Biologi }\end{array}$ & $\begin{array}{l}\text { Program full day school ini program } \\
\text { yang sangat bagus jika berjalan } \\
\text { dengan baik. Dari program ini kita } \\
\text { bisa membina moral siswa yang } \\
\text { saat ini kebanyakan tidak } \\
\text { mencerminkan sikap dan akhlak } \\
\text { yang baik sebagai seorang siswa. } \\
\text { Tetapi ini tidak bisa untuk disama } \\
\text { ratakan di semua sekolah. Bisa jadi, } \\
\text { di sekolah yang ada di kota program } \\
\text { ini sangat bagus, tetapi buat } \\
\text { sekolah-sekolah yang ada di desa } \\
\text { belum tentu cocok. }\end{array}$ \\
\hline
\end{tabular}

\footnotetext{
${ }^{23}$ Wawancara dengan Bapak Tengku Ahmad Avit selaku Wakil Kepala Sekolah Bidang Sarana Prasarana, wali kelas dan guru mata pelajaran Penjasorkes pada tanggal 7 Januari 2020 di Kantor Pembina.

${ }^{24}$ Wawancara dengan Ibu Rika Yosepa Koordinator PKG (Penilaian Kinerja Guru), wali kelas dan guru mata pelajaran Fisika pada tanggal 7 Januari 2020 di Ruang Guru.

${ }^{25}$ Wawancara dengan Ibu Euis Tuti Indrawati selaku Wakabid Kesiswaan, Wali Kelas dan guru mata pelajaran Biologi pada tanggal 10 Januari 2020 di Ruang Guru Piket.
} 


\begin{tabular}{|c|c|c|c|}
\hline 7 & $\begin{array}{c}\text { Shanti Wijaya, } \\
\text { S.Pd }\end{array}$ & $\begin{array}{c}\text { Wali Kelas XI IPA-3 } \\
\text { dan Guru Mata } \\
\text { Pelajaran Kimia }\end{array}$ & $\begin{array}{l}\text { Kalau maksud dari pemerintah itu } \\
\text { sudah benar ya, tinggal bagaimana } \\
\text { penerapannya di masing-masing } \\
\text { sekolah. Kan yang dimaksud } \\
\text { pemerintah itu dari hari senin } \\
\text { sampai jumat, Sedangkan di } \\
\text { sekolah ini hari sabtu masih masuk, } \\
\text { Cuma waktunya lebih longgar } \\
\text { karena hanya eskul saja. Tinggal } \\
\text { bagaimana kebijakan di sekolah } \\
\text { masing-masing. }\end{array}$ \\
\hline 8 & $\begin{array}{l}\text { Sugiarti Indah } \\
\text { Retno, S.Pd }\end{array}$ & $\begin{array}{c}\text { Guru Mata Pelajaran } \\
\text { Seni Budaya }\end{array}$ & $\begin{array}{l}\text { Menurut saya full day school itu ada } \\
\text { plus minusnya ya. Tergantung dari } \\
\text { bagaimana manajemen dan konsep } \\
\text { dari sekolah yang menerapkan } \\
\text { program tersebut. }{ }^{27}\end{array}$ \\
\hline 9 & $\begin{array}{c}\text { Ramahan } \\
\text { Fadel Al- } \\
\text { Mughni, S.Pd }\end{array}$ & $\begin{array}{c}\text { Guru Mata Pelajaran } \\
\text { PAI }\end{array}$ & $\begin{array}{l}\text { Full day school bisa dikatakan ada } \\
\text { positifnya ada negatifnya. Misalnya } \\
\text { jika anak sepulang sekolah siang } \\
\text { tapi tidak dikontrol oleh orang } \\
\text { tuanya, berarti kan full day school } \\
\text { ini baik. }{ }^{28}\end{array}$ \\
\hline
\end{tabular}

Dilihat dari tabel hasil wawancara diatas, bahwa sistem full day school yang diterapkan di sekolah mendapatkan berbagai macam persepsi dari masing-masing guru. Sebagian guru memberikan respon positif dengan adanya kebijakan pemerintah untuk menerapkan sistem full day school di sekolah-sekolah. Namun sistem ini akan berjalan dengan baik apabila sekolah tersebut mampu menunjang segala aspek yang dibutuhkan, dimulai dari sarana prasarana yang memadai, konsep dan manajemen yang tertata dan terlaksana dengan baik.

Di samping itu, adapula beberapa guru yang merasa bahwa pelaksanaan sekolah setengah hari/half day school lebih baik daripada sistem full day school. Hal ini dapat dilihat dari lingkungannya, jika di lingkungan tersebut masih terdapat sekolah agama atau Taman Pendidikan Al-Qur'an (TPQ) maka full day school tentunya tidak cocok diterapkan, karena dikhawatirkan sekolah agama dan Taman Pendidikan Al-Qur'an (TPQ) tersebut akan mengalami gulung tikar, sedangkan jam pelajaran agama di sekolah sangat terbatas hanya 3 jam dalam sepekan. Kemudian mereka menganggap bahwa sistem full day school akan lebih cocok apabila diterapkan di sekolah yang berada di daerah perkotaan, yang mana mayoritas

\footnotetext{
${ }^{26}$ Wawancara dengan Ibu Shanti Wijaya selaku Wali Kelas dan guru mata pelajaran Biologi pada tanggal 10 Januari 2020 di Ruang Guru.

${ }^{27}$ Wawancara dengan Ibu Sugiarti Indah Retno selaku Wali Kelas dan guru mata pelajaran Seni Budaya pada tanggal 10 Januari 2020 di Ruang Guru Piket.

${ }^{28}$ Wawancara dengan Bapak Ramadhan Fadel Al Mughni selaku guru mata pelajaran PAI pada tanggal 10 Januari 2020 di Ruang Pembina.
} 
orang tua bekerja sampai sore bahkan sampai malam sehingga membutuhkan sekolah yang dapat mengontrol anaknya selama orang tua bekerja.

\section{Persepsi Guru Tentang Kelebihan Full Day School}

Sistem full day school yang diterapkan di sekolah diharapkan dapat meningkatkan kualitas pendidikan dalam negeri utamanya dalam pembentukan karakter para pelajar. Dengan adanya sistem ini, tentunya ada kelebihan yang dimilikinya. Sebagaimana data yang peneliti dapatkan dari hasil wawancara dengan para narasumber tersaji dalam tabel berikut ini:

Tabel 3. Hasil Wawancara tentang Kelebihan Full Day School

\begin{tabular}{|c|c|c|c|}
\hline No & Nama & Jabatan & Hasil Wawancara \\
\hline 1 & $\begin{array}{l}\text { Dra. Vera } \\
\text { Sentra } \\
\text { Hutabarat }\end{array}$ & Kepala Sekolah & $\begin{array}{l}\text { Kelebihannya, mereka hari sabtu agak } \\
\text { longgar dan ada istirahatnya, dan mereka } \\
\text { bisa fokus belajar sehingga tidak } \\
\text { terganggu dengan yang lainnya. }{ }^{29}\end{array}$ \\
\hline 2 & $\begin{array}{l}\text { Asep } \\
\text { Kurniawan, } \\
\text { S.Pd }\end{array}$ & $\begin{array}{c}\text { Wakil Kepala } \\
\text { Sekolah Bidang } \\
\text { Kurikulum }\end{array}$ & $\begin{array}{l}\text { Anak lebih terkontrol di sekolah, anak } \\
\text { lebih terkendali dengan syarat memang } \\
\text { tidak ada jam kosong kecuali istirahat. } \\
\text { Dan juga dengan waktu yang panjang ya, } \\
\text { anak-anak bisa lebih menggali lagi bakat- } \\
\text { bakat mereka, misalnya memanfaatkan } \\
\text { waktu dengan mengikuti kegiatan eskul, } \\
\text { organisasi dll. }{ }^{30}\end{array}$ \\
\hline 3 & $\begin{array}{l}\text { Saepul Bahri, } \\
\text { S.Pd }\end{array}$ & $\begin{array}{c}\text { Pembina } \\
\text { Ekstrakurikuler } \\
\text { Rohani Islam } \\
\text { (Rohis), Wali } \\
\text { Kelas X IPA-2 } \\
\text { dan Guru Mata } \\
\text { Pelajaran PAI }\end{array}$ & $\begin{array}{l}\text { Akan meminimalisir tawuran antar siswa, } \\
\text { dan siswa juga akan fokus dalam } \\
\text { belajar. }{ }^{31}\end{array}$ \\
\hline 4 & $\begin{array}{l}\text { Tengku } \\
\text { Ahmad Avit, } \\
\text { S.Pd }\end{array}$ & $\begin{array}{l}\text { Wakil } \\
\text { Kurikulum } \\
\text { Bidang Sarana } \\
\text { dan Prasarana, }\end{array}$ & $\begin{array}{l}\text { Kelebihannya ya karena anak pagi sampai } \\
\text { sore di sekolah, jadi anak lebih terkontrol } \\
\text { aktivitasnya oleh guru. Dan juga dengan } \\
\text { jumlah waktu yang luas ya, anak-anak } \\
\text { dapat mengembangkan bakatnya mereka } \\
\text { masing-masing dengan mengikuti eskul }\end{array}$ \\
\hline
\end{tabular}

\footnotetext{
${ }^{29}$ Wawancara dengan Ibu Vera Sentra Hutabarat selaku Kepala Sekolah SMAN 1 Citeureup pada tanggal 10 Januari 2020 di Ruang Kepala Sekolah.

${ }^{30}$ Wawancara dengan Bapak Asep Kurniawan selaku Wakil Kepala Sekolah Bidang Kurikulum pada tanggal 10 Januari 2020 di Kantor Pembina.

${ }^{31}$ Wawancara dengan Bapak Saepul Bahri selaku Pembina Eskul Rohis, Wali Kelas dan Guru Mata Pelajaran PAI pada tanggal 7 Januari 2020 di Ruang Piket.
} 


\begin{tabular}{|c|c|c|c|}
\hline & & $\begin{array}{l}\text { Wali Kelas X } \\
\text { IPS-4 dan Guru } \\
\text { Mata Pelajaran } \\
\text { Penjasorkes }\end{array}$ & $\begin{array}{l}\text { ataupun kegiatan lainnya yang } \\
\text { bermanfaat. }^{32}\end{array}$ \\
\hline 5 & $\begin{array}{c}\text { Rika Yosepa, } \\
\text { M.Pd }\end{array}$ & $\begin{array}{c}\text { Koordinator } \\
\text { Penilaian } \\
\text { Kinerja Guru } \\
\text { (PKG), Wali } \\
\text { Kelas XII IPA- } \\
\text { 5, dan Guru } \\
\text { Mata Pelajaran } \\
\text { Fisika }\end{array}$ & $\begin{array}{l}\text { Keunggulannya, hal-hal negatif yang } \\
\text { memungkinkan anak-anak sepulang } \\
\text { sekolah lakukan bisa tercover atau } \\
\text { terkontrol sampai ashar. Dari pagi sampai } \\
\text { sore apa-apa sudah di kerjakan di sekolah, } \\
\text { jadi anak sudah tidak dibebankan lagi } \\
\text { tugas rumah/PR, hal tersebut bisa } \\
\text { menyenangkan siswa tinggal pulang ke } \\
\text { rumah dan istirahat. }\end{array}$ \\
\hline 6 & $\begin{array}{l}\text { Euis Tuti } \\
\text { Indrawati, } \\
\text { S.Pd }\end{array}$ & $\begin{array}{c}\text { Wakil Kepala } \\
\text { Sekolah Bidang } \\
\text { Kesiswaan, Wali } \\
\text { Kelas XII IPA- } \\
\text { 3, dan Guru } \\
\text { Mata Pelajaran } \\
\text { Biologi }\end{array}$ & $\begin{array}{l}\text { Manfaat dari adanya sekolah yang } \\
\text { memiliki program full day school sangat } \\
\text { terasa. Sekolah yang memiliki program } \\
\text { full day school ini lebih mengedepankan } \\
\text { akhlak. Mereka mengajarkan pendidikan } \\
\text { akhak lebih banyak sekaligus tentang } \\
\text { bagaimana penerapannya sehari-hari } \\
\text { sehingga anak-anak menjadi terbiasa. } \\
\text { Selain itu, sekolah yang memiliki } \\
\text { program full day school juga menjadi } \\
\text { jembatan atau solusi atas masalah yang } \\
\text { dialami anak-anak sekarang. Dimana } \\
\text { anak-anak sekarang banyak yang } \\
\text { terjerumus kepada pergaulan bebas, juga } \\
\text { pada permainan game-game online yang } \\
\text { tidak bermanfaat. }{ }^{34}\end{array}$ \\
\hline 7 & $\begin{array}{c}\text { Shanti } \\
\text { Wijaya, S.Pd }\end{array}$ & $\begin{array}{l}\text { Wali Kelas XI } \\
\text { IPA-3 dan Guru } \\
\text { Mata Pelajaran } \\
\quad \text { Kimia }\end{array}$ & $\begin{array}{l}\text { Kelebihannya bisa mengurangi hal-hal } \\
\text { negatif yang anak lakukan setelah pulang } \\
\text { sekolah misalnya tawuran. Intinya mah } \\
\text { anak-anak lebih terkontrol oleh gurunya } \\
\text { sampai sore di sekolah. }{ }^{35}\end{array}$ \\
\hline
\end{tabular}

\footnotetext{
${ }^{32}$ Wawancara dengan Bapak Tengku Ahmad Avit selaku Wakil Kepala Sekolah Bidang Sarana Prasarana, wali kelas dan guru mata pelajaran Penjasorkes pada tanggal 7 Januari 2020 di Kantor Pembina.

${ }^{33}$ Wawancara dengan Ibu Rika Yosepa Koordinator PKG (Penilaian Kinerja Guru), wali kelas dan guru mata pelajaran Fisika pada tanggal 7 Januari 2020 di Ruang Guru.

${ }^{34}$ Wawancara dengan Ibu Euis Tuti Indrawati selaku Wakabid Kesiswaan, Wali Kelas dan guru mata pelajaran Biologi pada tanggal 10 Januari 2020 di Ruang Guru Piket.

${ }^{35}$ Wawancara dengan Ibu Shanti Wijaya selaku Wali Kelas dan guru mata pelajaran Biologi pada tanggal 10 Januari 2020 di Ruang Guru.
} 


\begin{tabular}{|c|c|c|c|}
\hline 8 & $\begin{array}{c}\text { Sugiarti } \\
\text { Indah Retno, } \\
\text { S.Pd }\end{array}$ & $\begin{array}{c}\text { Guru Mata } \\
\text { Pelajaran Seni } \\
\text { Budaya }\end{array}$ & $\begin{array}{l}\text { Kelebihannya ya anak-anak jadi lebih } \\
\text { terkontrol oleh guru, karena dari pagi } \\
\text { sampai sore itu semua kegiatan sudah } \\
\text { tercover di sekolah. Dan juga dengan } \\
\text { adanya jadwal yang sudah tersusun } \\
\text { dengan rapih dari mulai kegiatan sholat } \\
\text { duha, belajar, istirahat dll, jadi anak } \\
\text { terlatih untuk disiplin waktu atau ya } \\
\text { mengoptimalkan waktunya dengan sebaik } \\
\text { mungkin. }{ }^{36}\end{array}$ \\
\hline 9 & $\begin{array}{c}\text { Ramadhan } \\
\text { Fadel Al- } \\
\text { Mughni, S.Pd }\end{array}$ & $\begin{array}{c}\text { Guru Mata } \\
\text { Pelajaran PAI }\end{array}$ & $\begin{array}{l}\text { Kelebihannya ya kegiatan anak-anak } \\
\text { terpantau oleh guru selama di sekolah. }{ }^{37}\end{array}$ \\
\hline
\end{tabular}

Dari hasil wawancara dengan para guru, sistem full day school memiliki banyak keunggulan. Tidak hanya itu, full day school juga menjadi solusi dalam mengatasi permasalahan yang ada saat ini. Hal-hal negatif yang memungkinkan siswa lakukan sepulang sekolah bisa terpantau dan terkontrol sampai sore. Selain itu, full day school dijadikan sebagai sarana atau tempat untuk membiasakan anak-anak dengan kegiatan-kegiatan yang lebih bermanfaat. Jadi, kelebihan atau keunggulan-keunggulan yang dimiliki oleh sekolah berbasis full day school ini menjadi daya tarik tersendiri bagi orang tua dan masyarakat yang ingin menyekolahkan anaknya di sekolah full day school.

\section{Persepsi Guru Tentang Kelemahan Full Day School}

Terlepas dari sisi positif atau kelebihannya, sistem full day school juga memiliki kelemahan yang menjadikan orang tua enggan untuk menyekolahkan anaknya di sekolah full day school. Dari hasil wawancara dengan para guru di SMAN 1 Citeureup, maka terdapat beberapa kelemahannya. Untuk memudahkan pembaca dalam melihat hasil wawancara mengenai kelemahan full day school, peneliti akan menyajikan data dengan menggunakan tabel dibawah ini:

\section{Tabel 4}

Hasil Wawancara tentang Kelemahan Full Day School

\begin{tabular}{|l|l|l|l|}
\hline No & Nama & Jabatan & Hasil Wawancara \\
\hline
\end{tabular}

\footnotetext{
${ }^{36}$ Wawancara dengan Ibu Sugiarti Indah Retno selaku Wali Kelas dan guru mata pelajaran Seni Budaya pada tanggal 10 Januari 2020 di Ruang Guru Piket.

${ }^{37}$ Wawancara dengan Bapak Ramadhan Fadel Al Mughni selaku guru mata pelajaran PAI pada tanggal 10 Januari 2020 di Ruang Pembina.
} 


\begin{tabular}{|c|c|c|c|}
\hline 1 & $\begin{array}{c}\text { Dra. Vera Sentra } \\
\text { Hutabarat }\end{array}$ & Kepala Sekolah & $\begin{array}{l}\text { Kelemahannya mungkin karena } \\
\text { sampai sore ya, mereka sudah } \\
\text { lelah. Sampai rumah, mereka } \\
\text { kurang bersosialisasi dengan } \\
\text { lingkungannya, waktu bersama } \\
\text { keluarganya juga kurang, lalu } \\
\text { untuk mereka yang les atau kursus } \\
\text { jadi tidak bisa karena di sekolah } \\
\text { sudah sampai sore. }{ }^{38}\end{array}$ \\
\hline 2 & $\begin{array}{c}\text { Asep Kurniawan, } \\
\text { S.Pd }\end{array}$ & $\begin{array}{c}\text { Wakil Kepala } \\
\text { Sekolah Bidang } \\
\text { Kurikulum }\end{array}$ & $\begin{array}{l}\text { Kelemahannya ya waktu anak- } \\
\text { anak bersosialisasi dengan } \\
\text { lingkungan rumahnya bahkan } \\
\text { orang tuanya itu sangat minim. } \\
\text { Lalu ada jam-jam dimana anak } \\
\text { merasa bosan atau lelah ya, } \\
\text { apalagi diatas jam } 13.00 \text { sampai } \\
\text { sore itu anak sudah lelah hingga } \\
\text { akhirnya tidak bisa fokus belajar. }\end{array}$ \\
\hline 3 & Saepul Bahri, S.Pd & $\begin{array}{c}\text { Pembina } \\
\text { Ekstrakurikuler } \\
\text { Rohani Islam } \\
\text { (Rohis), Wali } \\
\text { Kelas X IPA-2 } \\
\text { dan Guru Mata } \\
\text { Pelajaran PAI }\end{array}$ & $\begin{array}{l}\text { Kekurangannya anak-anak sangat } \\
\text { minim waktu sosialisasi dengan } \\
\text { lingkungan dan masyarakat sekitar } \\
\text { tempat tinggalnya karena siswa } \\
\text { lebih banyak di sekolah. }{ }^{40}\end{array}$ \\
\hline 4 & $\begin{array}{c}\text { Tengku Ahmad Avit, } \\
\text { S.Pd }\end{array}$ & $\begin{array}{c}\text { Wakil } \\
\text { Kurikulum } \\
\text { Bidang Sarana } \\
\text { dan Prasarana, } \\
\text { Wali Kelas X } \\
\text { IPS-4 dan Guru } \\
\text { Mata Pelajaran } \\
\text { Penjasorkes }\end{array}$ & $\begin{array}{l}\text { Kalau kelemahannya mungkin } \\
\text { anak-anak sering merasa jenuh } \\
\text { atau lelah terutama di jam-jam } \\
\text { setelah dzuhur. Dan juga karena } \\
\text { anak pulangnya sore bahkan } \\
\text { sampe maghrib, jadi waktu untuk } \\
\text { sosialisasi bersama keluarga atau } \\
\text { lingkungan sekitarnya jadi } \\
\text { berkurang bahkan tidak ada. }{ }^{41}\end{array}$ \\
\hline
\end{tabular}

\footnotetext{
${ }^{38}$ Wawancara dengan Ibu Vera Sentra Hutabarat selaku Kepala Sekolah SMAN 1 Citeureup pada tanggal 10 Januari 2020 di Ruang Kepala Sekolah.

${ }^{39}$ Wawancara dengan Bapak Asep Kurniawan selaku Wakil Kepala Sekolah Bidang Kurikulum pada tanggal 10 Januari 2020 di Kantor Pembina.

${ }^{40}$ Wawancara dengan Bapak Saepul Bahri selaku Pembina Eskul Rohis, Wali Kelas dan Guru Mata Pelajaran PAI pada tanggal 7 Januari 2020 di Ruang Piket.

${ }^{41}$ Wawancara dengan Bapak Tengku Ahmad Avit selaku Wakil Kepala Sekolah Bidang Sarana Prasarana, wali kelas dan guru mata pelajaran Penjasorkes pada tanggal 7 Januari 2020 di Kantor Pembina.
} 


\begin{tabular}{|c|c|c|c|}
\hline 5 & Rika Yosepa, M.Pd & $\begin{array}{c}\text { Koordinator } \\
\text { Penilaian } \\
\text { Kinerja Guru } \\
\text { (PKG), Wali } \\
\text { Kelas XII IPA- } \\
\text { 5, dan Guru } \\
\text { Mata Pelajaran } \\
\text { Fisika }\end{array}$ & $\begin{array}{l}\text { Fasilitias yang kurang dengan } \\
\text { jumlah jam yang banyak tentunya } \\
\text { siswa akan cepat bosan dalam hal } \\
\text { pemahaman atau efektifitas } \\
\text { pembelajaran bisa jadi kurang } \\
\text { efektif, karena yang kita tahu } \\
\text { anak-anak itu belajar maksimal di } \\
2 \text { jam pertama. Jadi benar-benar } \\
\text { guru itu harus menerapkan metode } \\
\text { pembelajaran } \\
\text { menyenangkan. Lalu anak-anak } \\
\text { merasa terkukung karena dari } \\
\text { senin-jumat belajar di sekolah, } \\
\text { sabtunya eskul, jadi merasa } \\
\text { kurang have fun. } 42\end{array}$ \\
\hline 6 & $\begin{array}{l}\text { Euis Tuti Indrawati, } \\
\text { S.Pd }\end{array}$ & $\begin{array}{c}\text { Wakil Kepala } \\
\text { Sekolah Bidang } \\
\text { Kesiswaan, Wali } \\
\text { Kelas XII IPA- } \\
\text { 3, dan Guru } \\
\text { Mata Pelajaran } \\
\text { Biologi }\end{array}$ & $\begin{array}{l}\text { Kalau untuk kekurangannya, } \\
\text { karena anak lama di sekolah jadi } \\
\text { tidak punya waktu untuk bermain } \\
\text { dan bersama keluarganya pun } \\
\text { lebih sedikit. Sosialisasi dengan } \\
\text { keluarga dan juga lingkunga } \\
\text { kurang dan anak mudah jenuh. }\end{array}$ \\
\hline 7 & Shanti Wijaya, S.Pd & $\begin{array}{l}\text { Wali Kelas XI } \\
\text { IPA-3 dan Guru } \\
\text { Mata Pelajaran } \\
\text { Kimia }\end{array}$ & $\begin{array}{l}\text { Kalau untuk kekurangannya, } \\
\text { anak-anak mungkin sepulang dari } \\
\text { sekolah datang ke rumah sudah } \\
\text { dalam keadaan lelah, sedangkan di } \\
\text { K13 itu anak-anak dituntut untuk } \\
\text { proaktif, jadi ya banyak tugas- } \\
\text { tugas mandiri atau kelompok yang } \\
\text { dikerjakan di luar jam sekolah. }{ }^{44}\end{array}$ \\
\hline 8 & Sugiarti Indah Retno & $\begin{array}{c}\text { Guru Mata } \\
\text { Pelajaran Seni } \\
\text { Budaya }\end{array}$ & $\begin{array}{l}\text { Kalau kekurangannya, di jam-jam } \\
\text { setelah dzuhur biasanya anak-anak } \\
\text { sudah merasa lelah, apalagi jika } \\
\text { jadwal pelajarannya seperti } \\
\text { matematika, fisika. }{ }^{4}\end{array}$ \\
\hline 9 & $\begin{array}{c}\text { Ramahan Fadel Al- } \\
\text { Mughni }\end{array}$ & $\begin{array}{c}\text { Guru Mata } \\
\text { Pelajaran PAI }\end{array}$ & $\begin{array}{l}\text { Biasanya kan saya suka kebagian } \\
\text { jam setelah dzuhur. Nah itu } \\
\text { tantangan banget buat saya } \\
\text { mengajar PAI, apalagi kalau }\end{array}$ \\
\hline
\end{tabular}

\footnotetext{
${ }^{42}$ Wawancara dengan Ibu Rika Yosepa Koordinator PKG (Penilaian Kinerja Guru), wali kelas dan guru mata pelajaran Fisika pada tanggal 7 Januari 2020 di Ruang Guru.

${ }^{43}$ Wawancara dengan Ibu Euis Tuti Indrawati selaku Wakabid Kesiswaan, Wali Kelas dan guru mata pelajaran Biologi pada tanggal 10 Januari 2020 di Ruang Guru Piket.

${ }^{44}$ Wawancara dengan Ibu Shanti Wijaya selaku Wali Kelas dan guru mata pelajaran Biologi pada tanggal 10 Januari 2020 di Ruang Guru.

${ }^{45}$ Wawancara dengan Ibu Sugiarti Indah Retno selaku Wali Kelas dan guru mata pelajaran Seni Budaya pada tanggal 10 Januari 2020 di Ruang Guru Piket.
} 


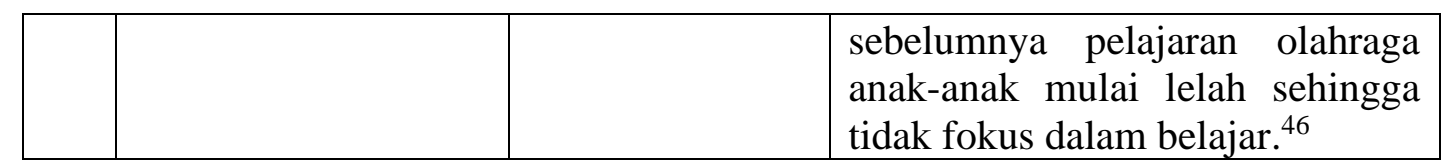

Dari hasil wawancara dengan para guru yang sudah dipaparkan diatas, maka beberapa kelemahan atau kekurangan dalam penerapan sistem full day school di SMAN 1 Citeureup terlihat dari teknis pembelajarannya. Diantaranya yaitu minimnya sosialisasi anak diluar sekolah atau dengan lingkungan tempat tinggalnya, anak-anak merasa terkukung atau minimnya kebebasan karena dari pagi hingga sore berada di sekolah, fasilitas yang kurang memadai juga berpengaruh pada pemahaman atau efektifitas pembelajaran, anak-anak merasa lelah atau bosan terutama di jam-jam setelah sholat dzuhur sehingga membuat mereka menjadi tidak fokus dalam belajar.

Akan tetapi, dengan adanya kelemahan-kelemahan dalam penerapan full day school, menjadikan guru-guru lebih termotivasi untuk mewujudkan pembelajaran full day school yang lebih baik ke depannya salah satunya yaitu dengan memberikan solusi untuk memperbaiki, mengatasi dan mengurangi kelemahan-kelemahan tersebut.

\section{Pengelolaan Pembelajaran Full Day School}

Pengelolaan pembelajaran atau konsep pembelajaran sebagaimana yang tertuang dalam Peraturan Pemerintah No. 19 Tahun 2005 Bab 1 Pasal 1 Ayat 9 tentang Standar Nasional Pendidikan meliputi perencanaan program, pelaksanaan serta evaluasi atau penilaian kegiatan pendidikan pada tingkat satuan pendidikan, kabupaten/kota, provinsi, atau nasional agar tercapai efisiensi dan efektivitas penyelenggaraan pendidikan. Di SMAN 1 Citeureup ini, penerapan full day school menggunakan Kurikulum 2013 dan manajemen berbasis sekolah (MBS) yang mana sekolah diberikan otonomi penuh untuk secara aktif, kreatif serta mandiri dalam mengembangkan dan melakukan inovasi dalam berbagai program untuk meningkatkan mutu pendidikan sesuai kebutuhan sekolah itu sendiri yang tidak lepas dari kerangka tujuan pendidikan nasional.

Untuk mengetahui bagaimana pengelolaan pembelajaran full day school di sekolah ini, maka peneliti melakukan wawancara dengan Wakil Kepala Sekolah Bidang Kurikulum yaitu Bapak Asep Kurniawan. Dalam wawancaranya, beliau memaparkan penjelasannya mengenai pengelolaan/konsep pembelajaran full day school yaitu:

“Kurikulum yang dipakai di sekolah ini yaitu Kurikulum 2013. Untuk konsepnya disini ada namanya pembagian tugas. Bagi yang Pegawai Negeri Sipil (PNS) minimal

\footnotetext{
${ }^{46}$ Wawancara dengan Bapak Ramadhan Fadel Al Mughni selaku guru mata pelajaran PAI pada tanggal 10 Januari 2020 di Ruang Pembina.
} 
24 jam mengajar, kemudian jam-jam yang masih kurang itu untuk guru-guru honorer dan sudah dalam Surat Keputusan (SK) pembagian tugas sehingga tidak terjadi bentrokan jadwal. PNS jelas harus sampai jam 16.00 di sekolah. Kalau dari segi manajemennya, diawal tahun pembelajaran kita mengadakan workshop, dan rapat kerja guru dimana kita menyiapkan administrasi pembelajaran yang harus dimiliki oleh masing-masing guru. Dimulai dari program tahunan. Program semester, analisis waktu, silabus, dan Rencana Pelaksanaan Pembelajaran (RPP). Karena beban kerja guru itu di mulai dari merencanakan pembelajaran, melaksanakan pembelajarannya lalu setelah itu menilai atau mengevaluasi. Itu semua harus disiapkan diawal tahun pembelajaran sehingga ketika guru mengajar itu semua sudah siap."

Sedangkan wawancara yang peneliti lakukan dengan Ibu Vera Sentra Hutabarat selaku Kepala Sekolah SMAN 1 Citeureup, yang berkaitan dengan administrasi guru yaitu:

"Sebetulnya untuk administrasi guru yang harus disiapkan itu banyak ya, akan tetapi yang wajib itu ada program tahunan (prota), program semester, silabus, Rencana Pelaksanaan Pembelajaran (RPP), daftar nilai, absensi dan analisis". ${ }^{48}$

Pengelolaan pembelajaran full day school di SMAN 1 Citeureup sesuai dengan apa yang tercantum dalam Peraturan Pemerintah No.19 Tahun 2005, yang mana dijelaskan bahwa standar pendidikan nasional itu meliputi perencanaan program, pelaksanaan serta evaluasi atau penilaian.

Pada awal tahun pelajaran, sekolah mengadakan rapat kerja untuk membuat dan merancang perencanaan pembelajaran selama setahun kedepan. Perencanaan pembelajaran yang dilakukan guru akan menentukan keberhasilan dalam pembelajaran. Semua guru harus menyerahkan komponen pembelajaran sebelum pembelajaran di tahun ajaran baru berlangsung efektif. Diantaranya yaitu program tahunan, program semester, silabus, Rencana Pelaksanaan Pembelajaran (RPP), daftar nilai, absensi dan analisis.

Setelah menyusun perancanaan, maka hal selanjutnya yaitu pada pelaksanaan dan evaluasi pembelajaran. Pelaksanaan pembelajaran itu sendiri merupakan implementasi dari Rencana Pelaksanaan Pembelajaran (RPP), yang mana meliputi kegiatan pendahuluan, kegiatan inti, dan kegiatan penutup. Sedangkan untuk kegiatan evaluasi/penilaian dalam proses pembelajaran merupakaan kegiatan mutlak yang harus dilakukan oleh guru. Melalui kegiatan ini, guru akan mengetahui tercapai atau tidaknya target/kemampuan siswa sesuai dengan apa yang telah disusun dan diharapkan oleh guru.

\footnotetext{
${ }^{47}$ Wawancara dengan Bapak Asep kurniawan selaku Wakil Kepala Sekolah Bidang Kurikulum dan guru Mata Pelajaran Matematika pada tanggal 10 Januari 2020 di Kantor Pembina.

${ }^{48}$ Wawancara dengan Ibu Vera Sentra Hutabarat selaku Kepala Sekolah SMAN 1 Citeureup pada tanggal 10 Januari 2020 di Kantor Kepala Sekolah.
} 
Novi Anggraeni, Baeti Rohman, Aas Siti Sholichah

\section{Kesimpulan}

Berdasarkan data hasil penelitian yang peneliti dapatkan tentang persepsi guru terhadap penerapan sistem full day school di SMAN 1 Citeureup, maka dapat diambil kesimpulan bahwa, kebijakan pemerintah dalam penerapan sistem full day school menuai berbagai macam persepsi di kalangan para guru. Sebagian guru memberikan respon positif terhadap kebijakan ini, bilamana sekolah tersebut mampu menunjang segala aspek yang dibutuhkan baik oleh guru maupun siswa, mulai dari konsep pengelolaan pembelajaran full day school yang terencana dengan baik, terstruktur dan terarah sehingga lebih efektif dalam menjalankan proses pembelajarannya serta pengembangan sarana dan prasarana yang memadai.

Persepsi guru tentang kelebihan sistem full day school yaitu sistem ini mampu menjadi solusi bagi para orang tua yang peduli terhadap krisis moral yang sedang dialami para siswa saat ini. Juga sebagai sarana perbaikan kualitas akhlak siswa menjadi lebih baik, dan untuk memaksimalkan waktu siswa agar lebih bermanfaat dengan mengembangkan bakat, minat dan kreativitas siswa. Persepsi guru tentang kelemahan sistem full day school yaitu terletak pada teknis pelaksanaannya. Siswa terkadang merasa bosan dan lelah terutama pada jam pelajaran setelah sholat dzuhur dan menjelang pulang sehingga tingkat fokus dan konsentrasi siswa berkurang, minimnya waktu sosialisasi siswa dengan lingkungan sekitar tempat tinggalnya serta keberaadaan sarana dan prasarana yang kurang memadai. Pengelolaan pembelajaran full day school di SMAN 1 Citeureup sesuai dengan yang tercantum dalam PP No. 19 Tahun 2005 Bab 1 Pasal 1 Ayat 9 tentang Standar Nasional Pendidikan yang berkaitan dengan perencanaan program, pelaksanaan pembelajaran, dan pengawasan atau evaluasi kegiatan pendidikan. 


\section{Daftar Pustaka}

Arbangi., et.al. Manajemen Mutu Pendidikan, Depok: Prenada Media Group, 2016.

Arikunto, Suharsimi. Dasar-dasar evaluasi pendidikan edisi 2. Jakarta: Bumi Aksara, 2012.

Asmani, Jamal Ma'mur. Full Day School Konsep Manajemen dan Quality Control, (Yogyakarta: Ar Ruzz Media, 2017).

Bakar, Rosdiana. Dasar-Dasar Kependidikan, Medan: Gema Insani, 2015.

Bekker, Anton. Metodologi Penelitian, Yogyakarta: Kanisius, 1992.

Baharudin. Pendidikan dan Psikologi Perkembangan, Yogyakarta: Ar Ruzz Media, 2010.

Burhanuddin, Jajat. Mencetak Muslim Modern, Jakarta: Rajawali Pers, 2006.

Departemen Pendidikan dan Kebudayaan, Kamus Besar Bahasa Indonesia, Jakarta: Balai Pustaka, 2009.

Departemen Pendidikan Nasional, Undang-Undang No. 20 Tahun 2003 Tentang Sistem Pendidikan Nasional, Jakarta: Depdiknas, 2003.

Departemen RI, Al-Quran dan Terjemahnya, Bandung: Sygma Examedia Arkanleema, 2009.

Harjanto. Perencanaan Pengajaran, Jakarta: Rineka Cipta, 2005.

Mahmud. Metode Penelitian Pendidikan, Bandung: Pustaka Setia, 2001.

Majid, Abdul. Perencanaan Pembelajaran, Bandung: PT. Remaja Rosdakarya, 2006.

Rugaiyah, dan Atiek Sismiati. Profesi Kependidikan, Bogor: Ghalia Indonesia, 2013.

Ruslan, Rosady. Metode Penelitian Public Relations dan Komunikasi, Jakarta: Raja Grafindo, 2008

Rusman. Model-Model Pembelajaran Mengembangkan Profesionalisme Guru, Jakarta: Rajawali Pers, 2016.

S. Nasution. Metode Penelitian Naturalistik Kualitatif, Bandung: Tarsito, 1996.

Sobur, Alex. Psikologi Umum Dalam Lintasan Sejarah, Bandung: Pustaka Setia, 2013.

Soeharto, Irwan. Metode Penelitian Sosial, Bandung: PT Remaja Rosdakarya, 1995.

Sugiyono. Metode Penelitian Kuantitatif Kualitatif dan R\&D, Bandung: Alfabeta, 2009.

Sukardi. Metode Penelitian Pendidikan Kompetensi dan Praktiknya, Jakarta: PT Bumi Aksara.

Sulistyaningsih, Wiwik. Full Day School Dan Optimalisasi Perkembangan Anak,Yogyakarta: Paradigma Indonesia, 2013.

Sumardi, Sumadi. Metodologi Penelitian, Jakarta: Rajawali Press, 1997.

Suyyinah. Full Day Education; Konsep dan Implementasi, Malang: CV Literasi Nusantara Abadi, 2019.

Syafaruddin, dkk. Ilmu Pendidikan Islam Melejitkan Potensi Budaya Umat, Jakarta: Hijri Pustaka Utama, 2014.

Wade, Carol, dan Carol Travis. Psokologi, Edisi Ke 9, Jakarta: Erlangga, 2009.

Winardi. Motivasi dan Pengorganisasian Dalam Manajemen, Jakarta: Rajawali Pers, 2008. 
Novi Anggraeni, Baeti Rohman, Aas Siti Sholichah

\section{Sumber Internet}

Http://disdikjabarprov.go.id. Diakses pada tanggal 17 Mei 2019.

Http://ejournal.umm.ac.id Diakses pada tanggal 15 Januari 2020.

Https://kbbi.web.id. Diakses pada tanggal 18 Desember 2019.

Https://m.antaranews.com. Diakses pada tanggal 17 Mei 2019.

Https://nasional.tempo.co. Diakses pada tanggal 17 Mei 2019.

Https://sekolah.datakemdikbud.go.id. Diakses pada tanggal 17 Mei 2019.

Https://silabus.web.id. Diakses pada tanggal 30 November 2019.

\section{Wawancara}

Dra. Vera Sentra Hutabarat, Kepala Sekolah

Asep Kurniawan, S.Pd, Wakil Kepala Sekolah Bidang Kurikulum

Saepul Bahri, S.Pd, Pembina Ekstrakurikuler Rohani Islam (Rohis), Wali Kelas X IPA-2 dan Guru Mata Pelajaran PAI

Tengku Ahmad Avit, S.Pd, Wakil Kurikulum Bidang Sarana dan Prasarana, Wali Kelas X IPS4 dan Guru Mata Pelajaran Penjasorkes

Rika Yosepa, M.Pd, Koordinator Penilaian Kinerja Guru (PKG), Wali Kelas XII IPA-5, dan Guru Mata Pelajaran Fisika

Euis Tuti Indrawati, S.Pd, Wakil Kepala Sekolah Bidang Kesiswaan, Wali Kelas XII IPA-3, dan Guru Mata Pelajaran Biologi

Shanti Wijaya, S.Pd, Wali Kelas XI IPA-3 dan Guru Mata Pelajaran Kimia

Sugiarti Indah Retno, Guru Mata Pelajaran Seni Budaya

Ramahan Fadhel Al-Mughni, Guru Mata Pelajaran PAI 
